$9.7 \mathrm{cM}$ (range 5-16 cM), and an average heterozygosity of 0.75 (range $0.63-0.87$ ). The PCR products were separated on $4 \%$ polyacrylamide gels on an ABI377 Sequencer (Perkin Elmer, Foster City, CA, USA), using the ABI GENESCAN/GENOTYPER software (Perkin Elmer). To confirm the genotypes, all markers were typed twice and scored independently by two individuals. Evidence for linkage was analysed using MAPMAKER/SIBS [6] and GENEHUNTER [7] and corrected for the effect of large sibships. The analyses did not demonstrate any significant evidence for linkage of NIDDM to chromosome 2 (Fig. 1, top panel). In particular, there was no evidence of linkage between NIDDM in this population and the marker D2S125 (observed heterozygosity 0.84 , and information content 0.64 ), which showed the strongest linkage in the Mexican-American sib-pairs [2] (Fig. 1, lower panel). This region of chromosome 2 was excluded for linkage (logarithm of odds score $\leq-2$, assuming $\lambda_{\mathrm{s}}=1.3$ ). Also, subgrouping of our study population for $\mathrm{BMI}$, age at onset, lipid values, or for the presence of hypertension did not lead to significant evidence for linkage.

Our results are not consistent with the notion that NIDDM1 constitutes a susceptibility gene for NIDDM in the Sardinian population, illustrating the difficulties in confirming findings in different populations, in particular when the $p$-value is close to the limit of genome-wide significance $(p=0.05)$ [8]. We are now in a good position to analyse the rest of the genome for the presence of important susceptibility genes for NIDDM and its associated phenotypes within the metabolic syndrome.

\section{Yours sincerely}

M. Ciccarese, G. Tonolo, I.Delin, F.K.Wong, P.Holm, M. M. Atzeni, P.Lichtenstein, I. Kockum, M. Maioli, H.Luthman, on behalf of the Study Group for the Genetics of Diabetes in Sardinia

Acknowledgements. The other members of The SGGDS: M.G.Melis, M.F.Angius, G.Secchi, G.Pala, N.Pintori, M. Manai, A.M. Sanna, R. M. Pilosu, A. Massidda, G. Meloni, R. Cirillo, E. Cossu, S. Mereu, A. Gigante, M. Mastinu, M.Cos- su, M.A. Mugheddu, A. Corda, G. Filigheddu, A. Cusseddu, F. Sanciu, E.Secchi, S. Loddoni, G. Idda, S. Lostia, G. Tocco and $M$. Loche.

This work was supported by grants from the Swedish Medical Research Council, the Swedish Diabetes Association, and the following foundations: Gamla Tjänarinnor, Novo Nordisk, Ulf Widengrens Minnesfond, Hedlunds Stiftelse.

The Study Group for the Genetics of Diabetes in Sardinia is supported by Novo Nordisk and Lifescan Sardinia.

\section{References}

1. Cavalli Sforza LL, Menotti P, Piazza A (1994) The history and geography of human genes. Princeton University Press, Princeton, New Jersey, pp 273-276

2. Hanis CL, Boerwinkle R, Chakraborty R et al. (1996) A genome-wide search for human non-insulin-dependent (type 2) diabetes genes reveals a major susceptibility locus on chromosome 2. Nat Genet 13: 161-166

3. Daly MJ, Lander ES (1996) The importance of being independent: sib pairs analysis in diabetes. Nat Genet 14: 131132

4. Hani EH, Hager T, Philippi A, Demenais F, Froguel P, Vionnet N (1997) Mapping NIDDM susceptibility loci in French families: Studies with markers in the region of NIDDM1 on chromosome 2q. Diabetes 46: 1225-1227

5. Murray JC, Buetow KH, Weber IL et al. (1994) A comprehensive human linkage map with centimorgan density. Cooperative Human Linkage Center (CHLC). Science 265: 2049-2054

6. Kruglyak L, Lander E (1995) Complete multipoint sib pair analysis of qualitative and quantitative traits. Am J Hum Gen 57: 439-454

7.' Kruglyak L, Daly MJ, Reeve-Daly MP, Lander ES (1996) Parametric and non parametric linkage analysis: a unified multipoint approach. Am J Hum Genet 58: 1347-1363

8. Lander E, Kruglyak L (1995) Genetic dissection of complex traits: guidelines for interpreting and reporting linkage results. Nat Genet 11: 241-247

\section{Glucokinase deficiency results in a beta-cell disorder characterised by normal fasting plasma proinsulin concentrations}

\section{Dear Sir,}

Patients with heterozygous mutations in the glucokinase gene have early-onset, mild stable hyperglycaemia $[1,2]$. Physiological studies have suggested that the hyperglycaemia in glucokinase deficiency results from a failure of the beta cell to sense glucose in keeping with the role of glucokinase as the pancreatic glucose sensor [2-5]. Fasting plasma intact proinsulin concentrations are increased both absolutely and relative to insulin in subjects with non-insulin-dependent diabetes mellitus (NIDDM) compared with normoglycaemic controls [6, 7]. Plasma proinsulin concentrations have not been reported in glucokinase deficiency.

Corresponding author: Dr. A.T.Hattersley, Department of Vascular Medicine and Diabetes Research, Postgraduate Medical School, Barrack Road, Exeter EX2 5AX, UK
We used specific immunoradiometric assays to measure fasting concentrations of insulin and intact proinsulin in 14 diet-treated subjects from maturity onset diabetes of the young (MODY) pedigree BX with a heterozygous missense mutation at position 299 in the glucokinase gene G299R [2, 5, 9]. Comparison was with 14 unrelated diet-treated NIDDM subjects (diagnosed after 40 years of age), individually matched for fasting plasma glucose (FPG) (within 10\%) and body mass in$\operatorname{dex}(\mathrm{BMI})$ (within $10 \%$ ) and with 14 obesity matched control subjects who came from pedigree $\mathrm{BX}$ but had been shown not to have a glucokinase mutation. The glucokinase, NIDDM and control groups were well-matched for BMI [median (interquartile range) 25.3 (23.8-26.9), 24.8 (23.7-28.3), 25.1 (22.527.6) $\mathrm{kg} / \mathrm{m}^{2}$ N.S.] and the two diabetic groups well-matched for FPG [7.0 (6.6-7.5), 7.2 (6.3-8.4) $\mathrm{mmol} / 1$ N.S.].

After a $12 \mathrm{~h}$ overnight fast, three arterialised samples were taken at 5-min intervals from the hand of a heated arm, following a 15-min period of rest. Plasma was separated within $1 \mathrm{~h}$ of the samples being taken and stored at $-20^{\circ} \mathrm{C}$. Plasma insulin and intact proinsulin, were determined by two-site immunoradiometric assays (IRMAs) as previously described [8]. Insulin-related peptides were measured in pooled plasma from the three fasting samples. Comparison of groups was initially 
Table 1. Fasting insulin related peptide concentrations in glucokinase (GCK) deficiency, NIDDM and normal subjects

\begin{tabular}{|c|c|c|c|c|c|c|}
\hline & $\begin{array}{l}\text { Glucokinase } \\
\text { deficient } \\
(n=14)\end{array}$ & $\begin{array}{l}p \text { value } \\
\text { (GCK vs } \\
\text { NIDDM) }\end{array}$ & $\begin{array}{l}\text { NIDDM } \\
(n=14)\end{array}$ & $\begin{array}{l}p \text { value } \\
\text { (NIDDM vs } \\
\text { normal) }\end{array}$ & $\begin{array}{l}\text { Normal } \\
(n=14)\end{array}$ & $\begin{array}{l}p \text { value } \\
\text { (Normal vs } \\
\text { GCK) }\end{array}$ \\
\hline Insulin (pmol/1) & $41(25-76)$ & NS & $41(23-72)$ & NS & $42(23-76)$ & NS \\
\hline Proinsulin/Insulin ratio (\%) & $6(3-8)$ & $<0.01$ & $13(9-14)$ & $<0.01$ & $7(4-9)$ & NS \\
\hline
\end{tabular}

Data presented as geometric mean (standard deviation range) except for proinsulin/insulin ratio which is shown as median (interquartile range).

$\mathrm{NS}=p>0.05$

performed with a one-way ANOVA and when this showed significant deviation between groups, an unpaired Student's $t$-test was used to compare groups with logarithmic transformation where appropriate. The fasting insulin and intact proinsulin concentrations measured by IRMA are shown in Table 1.

This study showed that subjects in the glucokinase-deficiency subgroup of diabetes have normal fasting proinsulin concentrations in contrast to the raised concentrations seen in nonobese NIDDM subjects with a similar degree of hyperglycaemia. Fasting insulin concentrations measured speficically by IRMA were similar in diabetic and normoglycaemic members of our glucokinase-deficient pedigree. This reflected inappropriately low insulin secretion for the hyperglycaemia found in the diabetic subjects. This confirms that hyperglycaemia in glucokinase deficiency predominantly results from beta-cell dysfunction as shown by other studies using hyperglycaemic clamps [3], continuous glucose infusions [5] and homeostasis model assessment (HOMA) modelling using fasting RIA insulin and glucose values [2].

Are glucokinase deficient patients pathophysiologically distinct from other patients with NIDDM? The similar fasting insulin and glucose concentrations suggested a similar degree of beta-cell dysfunction in the glucokinase deficient patients and the matched NIDDM subjects. However, the difference in proinsulin concentrations supports the idea that there is a qualitative difference in the type of beta-cell dysfunction. Proinsulin in glucokinase-deficient subjects represented $6 \%$ of the fasting insulin - a similar level to that measured in matched normoglycaemic control subjects. This result suggests that in glucokinase deficiency the processing of insulin may be relatively normal even in the presence of chronic hyperglycaemia. The near normal concentration of proinsulin despite hyperglycaemia is in keeping with a failure to sense glucose by the pancreatic beta cell. This would fit with theoretical considerations of the role of glucokinase and physiological observations on patients with glucokinase deficiency in response to graded glucose infusions [4]. Although our subjects have a single mutation it is likely that as the majority of the other mutations have similar clinical and functional characteristics $[1,10]$, they will have similar proinsulin and insulin concentrations.

In conclusion glucokinase deficiency is characterized by a beta-cell defect in which the proportion of insulin-related peptides secreted as proinsulin was normal. This result would be consistent with an abnormality of glucose sensing. The finding of an elevated proinsulin ratio in obesity- and glycaemia-matched NIDDM subjects suggests that the beta-cell defect in these subjects is not a failure of glucose sensing. A normal proinsulin/insulin ratio should be considered one of the characteristics of glucokinase mutations although such measurements on their own are insufficient to differentiate glucokinase deficiency from non-glucokinase NIDDM.

Yours sincerely,

A.T.Hattersley, P.M.Clark, R.Page, J.C.Levy, L.Cox, C. N. Hales, R.C. Turner

\section{References}

1. Froguel P, Zouali H, Vionnet N et al. (1993) Familial hyperglycaemia due to mutations in glucokinase. Definition of a subtype of diabetes mellitus. New Engl J Med 328: 697-702

2. Hattersley AT, Turner RC, Permutt MA et al. (1992) Linkage of type 2 diabetes to the glucokinase gene. Lancet 339 : 1307-1310

3. Velho G, Froguel P, Clement K et al. (1992) Primary pan* creatic beta-cell secretory defect caused by mutations in glucokinase gene in kindreds of maturity onset diabetes of the young. Lancet 340: 444-448

4. Byrne MM, Sturis J, Clement K et al. (1994) Insulin secretory abnormalities in subjects with hyperglycaemia due to glucokinase mutations. J Clin Invest 93: 1120-1130

5. Page RC, Hattersley AT, Levy JC et al. (1995) Clinical characteristics of subjects with a missense mutation in glucokinase. Diabet Med 12: 209-217

6. Gorden P, Hendricks CM, Roth J (1974) Circulating proinsulin-like component in man: increased proportion in hyperinsulinaemic states. Diabetologia 10: 469-474

7. Temple RC, Carrington CA, Luzio SD et al. (1989) Insulin deficiency in non-insulin-dependent diabetes. Lancet i: 293-295

8. Sobey WJ, Beer SF, Carrington CA et al. (1989) Sensitive and specific two-site immunoradiometric assays for human insulin, proinsulin, $65-66$ split and 32-33 split proinsulins. Biochem J 260: 535-541

9. Stoffel M, Patel P, Lo Y-MD et al. (1992) Missense mutation in maturity-onset diabetes of the young and mutation screening in late-onset diabetes. Nature Genetics 2: 153156

10. Gidh-Jain M, Takeda J, Xu LZ et al. (1993) Glucokinase mutations associated with non-insulin-dependent (type 2) diabetes mellitus have decreased enzymatic activity: implications for structure/function relationships. Proc Natl Acad Sci (USA) 90: 1932-1936 